Цитування на цю статтю:

Черненко СО, Олійник ОМ, Сорокін ЮС, Коваль ОБ. Дослідження освітнього процесу підготовки майбутніх викладачів за спеціальністю “Фізична культура і спорт”. Вісник Прикарпатського університету. Серія: Фізична культура. 2020 Листоп 24; 36: 86-94

\begin{tabular}{|c|c|}
\hline Відомості про автора: & Information about the author: \\
\hline $\begin{array}{l}\text { Черненко Сергій Олександрович - кандидат наук } 3 \\
\text { фізичного виховання та спорту, доцент, Донбаська } \\
\text { державна машинобудівна академія (Краматорськ, } \\
\text { Україна) }\end{array}$ & $\begin{array}{l}\text { Chernenko Sergiy Oleksandrovych - Candidate of } \\
\text { Science (Physical Education and Sport), Associate } \\
\text { Professor (Ph. D.), Donbas State Engineering Aca- } \\
\text { demy (Kramatorsk, Ukraine) }\end{array}$ \\
\hline \multicolumn{2}{|l|}{$\begin{array}{l}\text { e-mail: chernenko.sergey65@ukr.net } \\
\text { https://orcid.org/0000-0001-9375-4220 }\end{array}$} \\
\hline $\begin{array}{l}\text { Олійник Олег Миколайович - старший викладач, } \\
\text { завідувач кафедри фізичного виховання і спорту, } \\
\text { Донбаська державна машинобудівна академія } \\
\text { (Краматорськ Україна) }\end{array}$ & $\begin{array}{l}\text { Oliynyk Oleh Mykolayovych - lecturer, Donbas State } \\
\text { Engineering Academy (Kramatorsk, Ukraine). }\end{array}$ \\
\hline \multicolumn{2}{|l|}{$\begin{array}{l}\text { e-mail: olegoliynyk@ukr.net } \\
\text { http://orcid.org/0000-0002-9197-1034 }\end{array}$} \\
\hline $\begin{array}{l}\text { Сорокін Юрій Сергійович - старший викладач, } \\
\text { Донбаська державна машинобудівна академія } \\
\text { (Краматорськ Україна) }\end{array}$ & $\begin{array}{l}\text { Sorokin Yuriy Serhiyovych - lecturer, Donbas State } \\
\text { Engineering Academy (Kramatorsk, Ukraine) }\end{array}$ \\
\hline \multicolumn{2}{|l|}{$\begin{array}{l}\text { e-mail: ur.sorokin65@ gmail.com } \\
\text { http://orcid.org/0000-0001-5185-5111 }\end{array}$} \\
\hline $\begin{array}{l}\text { Коваль Олег Борисович - викладач фізичного ви- } \\
\text { ховання, гімназія “Інтелект" (Дружківка, Україна) }\end{array}$ & $\begin{array}{l}\text { Koval Oleg Borysovych - lecturer, high school } \\
\text { "Intellect" (Druzhkivka,Ukraine) }\end{array}$ \\
\hline $\begin{array}{l}\text { e-mail: yevgenkoval20@gmail.com } \\
\text { http://orcid.org/0000-0003-1257-6966 }\end{array}$ & \\
\hline
\end{tabular}

УДК 796.155.9

doi: 10.15330/fcult.36.94-101

\section{Василь Хлопецький, Сергій Курилюк, Андрій Мельник, Олена Мельник}

\title{
ПРОФЕСІЙНЕ САМОВИЗНАЧЕННЯ ТА ВМОТИВОВАНІСТЬ ДО РУХОВОЇ АКТИВНОСТІ СТУДЕНТОК ПЕДАГОГІЧНИХ СПЕЦІАЛЬНОСТЕЙ
}

Мета. 3'ясувати вмотивованість студенток педагогічних спечіальностей до занять фізичною культурою. Методи. В роботі використані: теоретичний аналіз, психологічні та педагогічні методи дослідження, анкетування. Результати. 3'ясовано, щуо понад 50 \% студенток задоволені своїм професійним вибором. Вони мають чіткий намір оволодіти обраним фахом; хочуть у майбутньому здійснювати діяльність по професї та удосконалюватися у вибраному напрямку; знаходять час для занять справами, які стосуються обраної професії; прагнуть мати колег у обраній сфері; виділяють свою професію серед інших. Високий рівень інтересу до занять фізичною культурою виявили 20,93\% студенток, 32,95\% - високий, 25,19\% - середній, низький - 11,4, а 9,69\% такоӥ иікавості не мають. Найбільш поширеними мотивами до занять фізичною культурою для студенток є зміцнення здоров'я (98,84 \%), поліпшення власної фізичної підготовленості (84,50\%) i покращення тіло будови (41,86 \%). Висновок. Основними причинами, які є перепоною для занять фізичною культурою є дефіцит часу $(51,55 \%)$, поганий стан здоров'я (20,54\%), відсутність спортивних секцій, які б їх зацікавили (11,24\%), спортивної інфраструктури (4,65\%), партнерів для занять фізичними вправами (10,85\%), спортивного одягу і взуття $(9,69 \%)$.

Ключові слова: фізична культура, студентки, мотиви.

The aim. To find out the motivation of students of pedagogical specialties to physical education classes. Methods. The paper uses: theoretical analysis, psychological and pedagogical research methods, questionnaires. Results. It was found that more than 50\% of female students are satisfied with their professional choice. They have a clear intention to master the chosen profession, because they like it; want in the future by profession and to improve in the chosen direction; find time to do things related to the chosen profession; seek to have colleagues in the chosen field; distinguish their profession among others. A high level of interest in physical 
education was shown by $20.93 \%$ of female students, $32.95 \%$ - high, $25.19 \%$ - medium, low - 11.4, and 9.69\% have no such interest. Conclusion. The most common motives for physical education for female students are to strengthen their health (98.84\%), improve their physical fitness (84.50\%) and improve their body structure $(41.86 \%)$. The main reasons that are an obstacle to physical culture are lack of time (51.55\%), poor health (20.54\%), lack of sports sections that would interest them (11.24\%), sports infrastructure ( $4.65 \%)$, exercise partners $(10.85 \%)$, sportswear and footwear $(9.69 \%)$.

Keywords: physical culture, students, motives.

Постановка проблеми та аналіз результатів останніх досліджень. Рівень професійної спрямованості є вагомим фактором, який впливає на наполегливість та успішність у будь-якому виді діяльності - як навчальної, так і професійної після закінчення закладів вищої освіти $[4,5,6]$.

Фізична культура - один із важливих засобів різнобічного та гармонійного розвитку студентської молоді, підвищення іiі фізичної підготовленості та збереження здоров'я $[1,2,3,4]$. За нинішніх умов онлайн навчання, яке посилює дефіцит рухової активності (гіпокінезії), суттєво зменшується як рівень розумової, так і фізичної працездатності, що негативно впливає на стан професійної підготовки та функціональні резерви організму, а відтак і здоров'я студентів [5, 6].

Мета дослідження - 3'ясувати вмотивованість студенток педагогічних спеціальностей до занять фізичною культурою.

Методи дослідження. Під час дослідження використовували теоретичний аналіз і узагальнення науково-методичної літератури, соціологічні методи (анкетування, бесіди). Кількісні показники піддані статистичній обробці.

Анкетування і бесіди проводились задля отримання інформації щодо задоволення від вибору професії та занять фізичною культурою, а також для виявлення пріоритетних видів рухової активності, які студентки використовують під час самостійних занять. Для анкетування використовували анкету розроблену Н.Земською [16]. Дослідження проводилось серед 258 студенток Прикарпатського національного університету імені Василя Стефаника.

Результати дослідження. Аналіз результатів показав, що менше ніж 50\% студенток мають високий рівень задоволення вибором професії, а понад 40\% тільки низький і середній і зовсім мало тих хто має достатній рівень цього показника (рис. 1).

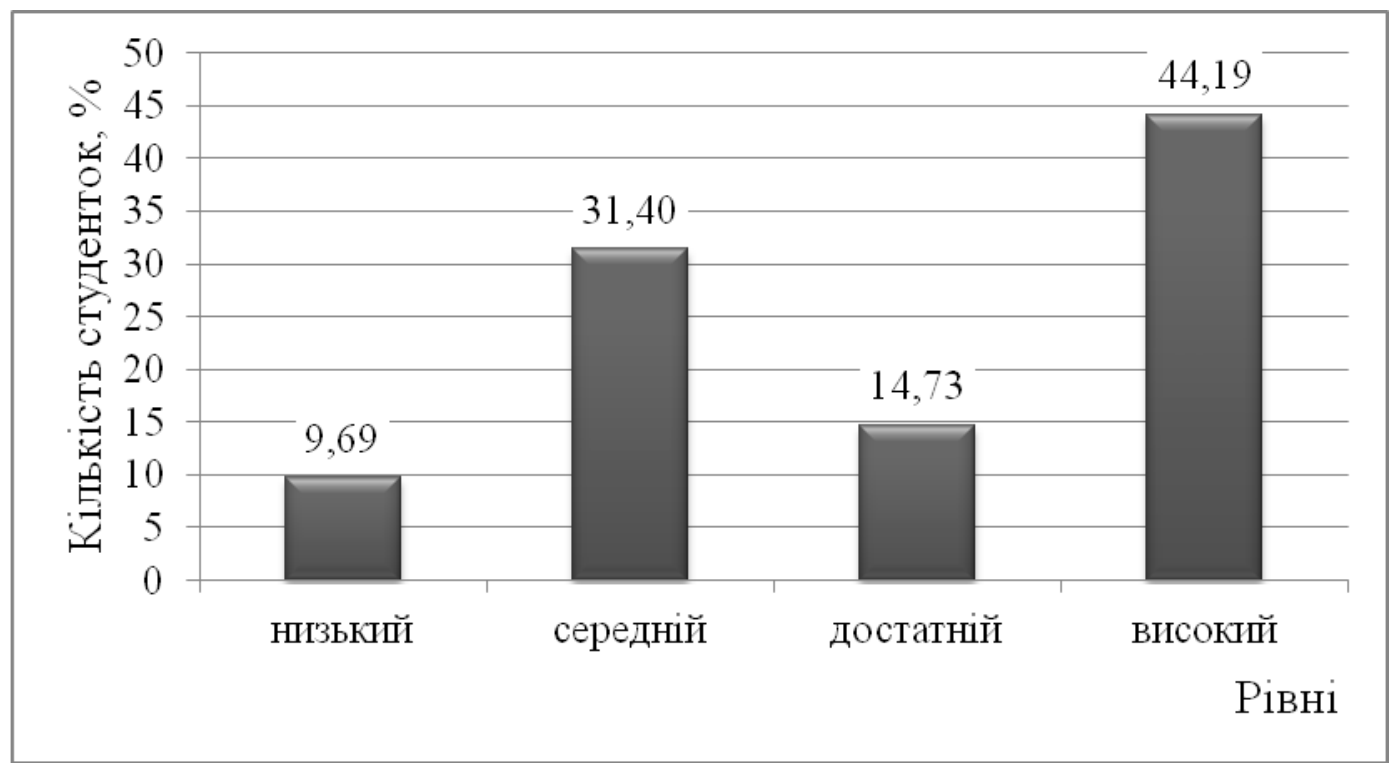

Рuc. 1. Розподіл студенток за рівнями задоволення від вибору професії $(\mathrm{n}=258), \%$. 
Низькі показники свідчать про те, що студентки не є належним чином мотивовані до навчання, а вступ до закладу вищої освіти зумовлений не інтересом до майбутнього фаху, а низкою інших причин, таких як наполягання батьків, близькість розташування освітнього закладу тощо. Такі студентки, очевидно, у разі наявної можливості охоче змінять обраний фах.

Відзначимо, що студенти, які мають достатній і високий рівні задоволення від професійного вибору прагнуть оволодіти обраною професією, хочуть у майбутньому працювати й здійснювати безперервне професійне навчання; у вільний, від навчання, час намагаються займатися справами, які стосуються обраного фаху; прагнуть мати друзів-спеціалістів у обраній сфері; вважають свою професію престижною.

Нами також визначалось ставлення студенток до засобів фізичної підготовки як вагомого чинника зміцнення власного здоров'я, а відтак і покращення психоемоційного стану.

Показники інтересу студенток до занять фізичною культурою наведені на рис. 2.

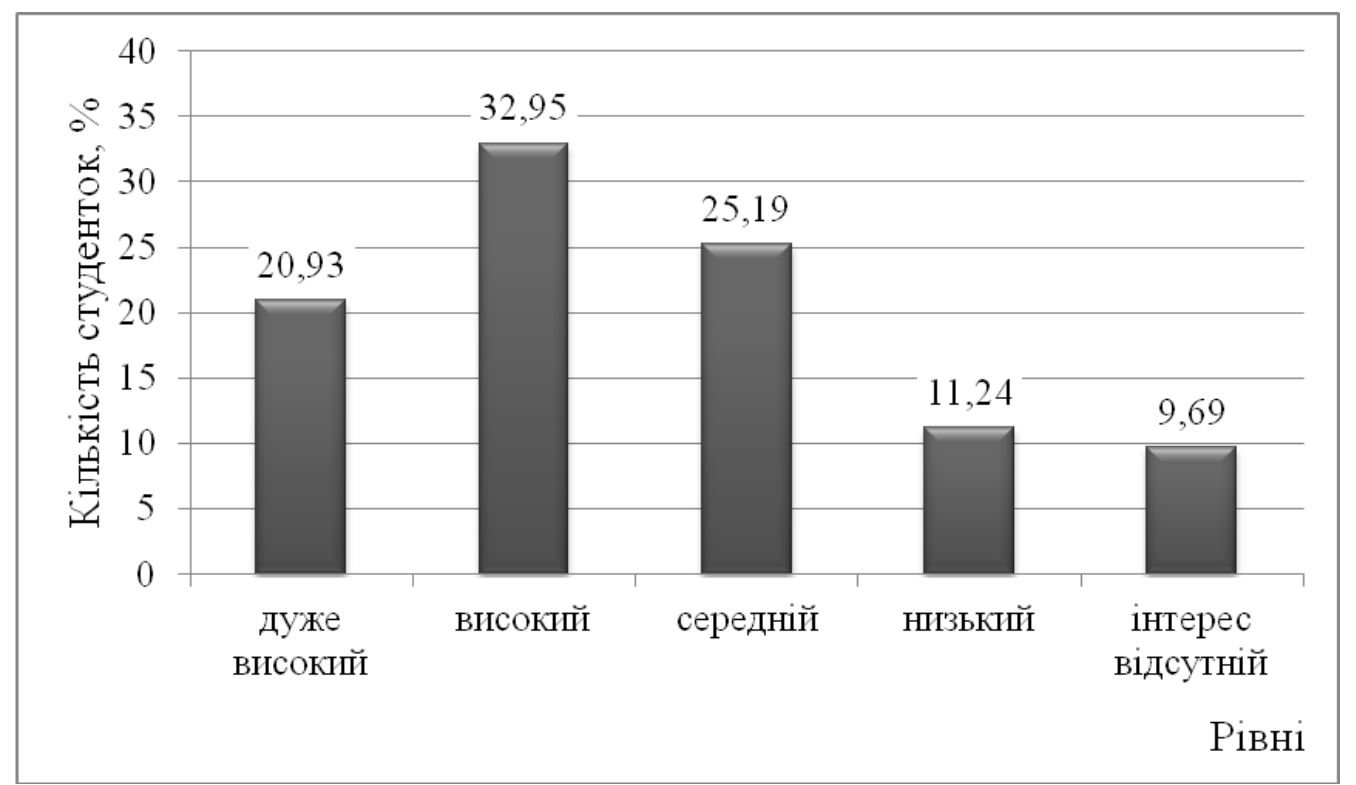

Рис. 2. Розподіл студенток за рівнями інтересу до занять фізичною культурою $(\mathrm{n}=258)$.

Як бачимо з рис. 2, високий і дуже високий рівень інтересу притаманний понад 50-ти відсоткам студентів, але більше 20\% мають низький рівень цього показника, а то й відсутність цікавості до занять фізичними і спортивними вправами взагалі.

Слід зазначити, що виявлений високий і дуже високий інтерес до занять фізичною культурою у значної частини студенток ще не засвідчує про їх остаточне ставлення до рухової активності та систематичних занять фізичними і спортивними вправами. Так, на запитання “Чи займались Ви раніше у спортивній секції?” 38,76\% студенток відповіли “так”, серед них 3,49\% мають спортивний розряд. Проте $61,24 \%$ не займались раніше в жодній спортивній секції чи гуртку.

Однак на питання “Чи хотіли б Ви зараз займатися в спортивній секції?” позитивно відповіли 35,27\% студенток, а 64,73\% відповіли, що ні.

Викликає інтерес прояв у студенток емоційно-вольового компоненту щодо занять фізичною культурою (табл. 1).

Як видно $з$ табл. 1, найчисельніша група студенток з великим бажанням займаються фізичною культурою під час навчання. Більше третини визнали, що відвідують заняття фізичною культури без особливого бажання, або й взагалі воно відсутнє. 


\begin{tabular}{|c|c|}
\hline Показники емоційно-вольового відношення до занять фізичною культурою (n = 258), \% & $\begin{aligned} & \text { Таблищя } \\
= & 258), \%\end{aligned}$ \\
\hline \multicolumn{2}{|c|}{ Чи подобається Вам займатися фізичною культурою? } \\
\hline Відвідую заняття з великим бажанням & 68,22 \\
\hline Відвідую на заняття без особливого бажання & 30,23 \\
\hline Відвідую на заняття без бажання & 1,55 \\
\hline \multicolumn{2}{|c|}{ Як часто Ви пропускаєте заняття з фізичної культури? } \\
\hline Практично не пропускаю & 79,46 \\
\hline Пропускаю 3-4 рази за семестр; & 10,85 \\
\hline Пропускаю більше 5 разів за семестр. & 9,69 \\
\hline \multicolumn{2}{|c|}{ Після занять фізичною культурою Ваше самопочуття } \\
\hline погіршується; & - \\
\hline залишається без змін & 40,31 \\
\hline стає кращим & 59,69 \\
\hline \multicolumn{2}{|c|}{ За останні роки Ваш стан здоров'я: } \\
\hline Покращився & 56,59 \\
\hline Залишився без змін & 31,40 \\
\hline Погіршився & 12,02 \\
\hline \multicolumn{2}{|c|}{ Чи відчуваєте Ви втому після занять у навчальному закладі? } \\
\hline Так і досить швидко & - \\
\hline Так, але після тривалої і напруженої роботи & 87,60 \\
\hline Дуже рідко, практично ніколи & 12,40 \\
\hline
\end{tabular}

Щодо відвідування занять, то в цілому його можна визнати як таким, що знаходиться на належному рівні (див. табл. 1).

Значна частина студентської молоді відзначили, що після занять фізичною культурою їх самопочуття покращується. Проте є й такі, які мають певний дискомфорт (див. табл. 1).

Аналіз результатів самооцінки власного стану здоров'я за останні роки засвідчує наявність його покращення, але понад третина студентів не фіксують покращення, а навіть і його погіршення (див. табл. 1).

Порівняно незначний відсоток студентів стверджує, що їх навчальна діяльність призводить до надмірного стомлення (див. табл. 1).

Результати анкетування показали, що студентки добре усвідомлюють вплив занять фізичною культурою на організм людини (95,0\% вказують на зміцнення здоров’я, $81,8 \%$ поставили за рейтингом на другу позицію удосконалення фізичного розвитку та підвищення фізичної підготовленості, 53,88\% вбачають їх вплив на розвиток моральних, вольових та естетичних якостей).

Виявлено, що студенти в цілому правильно розуміють мету фізичної культури в ЗВО (24,4\% вбачають іiі мету у формуванні рухових навиків, 25,2\% - у формуванні потреб і мотивів до регулярних занять фізичною культурою, 16,6\% - у формуванні спеціальних знань у галузі фізичної культури і спорту). При цьому, тільки незначна кількість студентів $(3,5 \%)$ вказують на ії професійно-прикладне значення.

У табл. 2 наведені результати, які характеризують відношення студенток до здоров'язберігаючих чинників, а відтак і до способу життя (ЗСЖ). Як виявлено, майже 80\%, понад третину засосовують засоби і методи загартування, але, на жаль, тільки половина з опитаних здійснюють регулярне медичне обстеження.

Як відомо, важливим чинником у здоров'язбереженні є раціональне харчування. Отримані дані доводять, що студентки недооцінюють його значення (див. табл. 2). Як бачим 3 даної таблиці тільки 66\% дотримуються режиму харчування (3-4 рази на добу).

Щодо тривалості сну, то гігієнічної норми (7-8 годин) дотримується 45,35\% студенток (див. табл. 2). 
Серед студенток не було виявлено жодного випадку стосовно паління, вживання алкоголю і наркотиків. Це засвідчує про усвідомлення майбутніми педагогічними працівниками негативної дії названих чинників на організм людини.

Важливою умовою відношення особистості до занять фізичною культурою є наявність усвідомлених мотивів [6].

Аналіз результатів дослідження (табл. 3) засвідчує, що найбільш поширеним мотивом до занять фізичною культурою для студенток є “зміцнення здоров”я”.

Здоров'язберігаючі чинники способу життя студенток $(\mathbf{n}=258), \%$

\begin{tabular}{|l|c|}
\hline Виконання ранкової гімнастики & 42,25 \\
\hline Самостійні заняття фізичними вправами протягом дня & 78,29 \\
\hline Загартування & 39,92 \\
\hline Регулярне медичне обстеження & 59,30 \\
\hline Дотримання режиму дня & 51,94 \\
\hline Організація харчування (кратність) & \\
\hline 2 рази на добу; & 13,18 \\
\hline 3 рази на добу; & 63,95 \\
\hline р рази на добу & 2,33 \\
\hline Тривалість нічного сну & \\
\hline до 7 годин & 34,11 \\
\hline $7-8$ годин & 45,35 \\
\hline більше 8 годин & 1,16 \\
\hline Систематичний догляд за гігієною тіла, одягу та взуття & 67,83 \\
\hline Паління, вживання алкогольних напоїв, наркотиків & - \\
\hline
\end{tabular}

Великий відсоток студентської молоді відвідує заняття з фізичної культури для поліпшення власної фізичної підготовленості. Мотив "Мати гарну тіло будову поставлений більшістю на третю і четверту позиції (табл. 3). Щодо мотиву “Оволодіння технікою виконання спортивних вправ”, то він є важливим для майже третини студенток. Водночас, частина студентської молоді відвідує заняття через мотив спілкування з товаришами (див. табл. 3), а такий мотив як уникнення неприємностей, пов'язаних із пропусками занять, не мав чітко вираженої картини. Неочікуваним було остання місце в рейтингу такого мотиву як “інтерес до викладача” (див. табл. 3).

Таблиия 3

Мотиви студенток до занять фізичною культурою $(\mathrm{n}=\mathbf{2 5 8}), \%$

\begin{tabular}{|l|c|c|c|c|c|c|c|c|}
\hline \multicolumn{1}{|c|}{ Мотиви } & \multirow{2}{*}{ Ранг } & \multicolumn{7}{|c|}{ \% за місцями } \\
\cline { 3 - 10 } & I & 98,84 & 1,16 & - & - & - & - & - \\
\hline Зміцнити здоров'я & II & 2,33 & 84,50 & 13,18 & - & - & - & - \\
\hline $\begin{array}{l}\text { Підвищити фізичну підготов- } \\
\text { леність }\end{array}$ & III & - & - & 41,86 & 54,65 & 1,16 & 1,16 & 1,16 \\
\hline Мати гарну будову тіла & IV & - & 9,69 & 34,11 & 39,53 & 14,34 & 1,16 & 1,16 \\
\hline $\begin{array}{l}\text { Оволодіти технікою видів } \\
\text { спорту }\end{array}$ & V & - & 1,16 & 1,16 & 3,49 & 53,49 & 40,70 & - \\
\hline Поспілкуватися з товаришами & VI & - & 2,33 & 9,69 & 2,33 & 29,84 & 41,47 & 14,34 \\
\hline $\begin{array}{l}\text { Уникнути неприємностей, по- } \\
\text { в'язаних із пропусками занять }\end{array}$ & VII & - & - & - & - & 1,16 & 15,50 & 83,33 \\
\hline Інтерес до особи викладача
\end{tabular}


Результати дослідження щодо причин, які заважають студенткам займатися руховою активністю показані на рис. 4. Як бачимо, основними причинами, які заважають студенткам займатись фізичною культурою є дефіцит часу, поганий стан здоров'я, відсутність спортивних секцій, які б їх зацікавили, спортивної інфраструктури, партнерів для занять фізичними вправами, відсутність спортивного одягу і взуття та бажання займатися фізичними вправами.

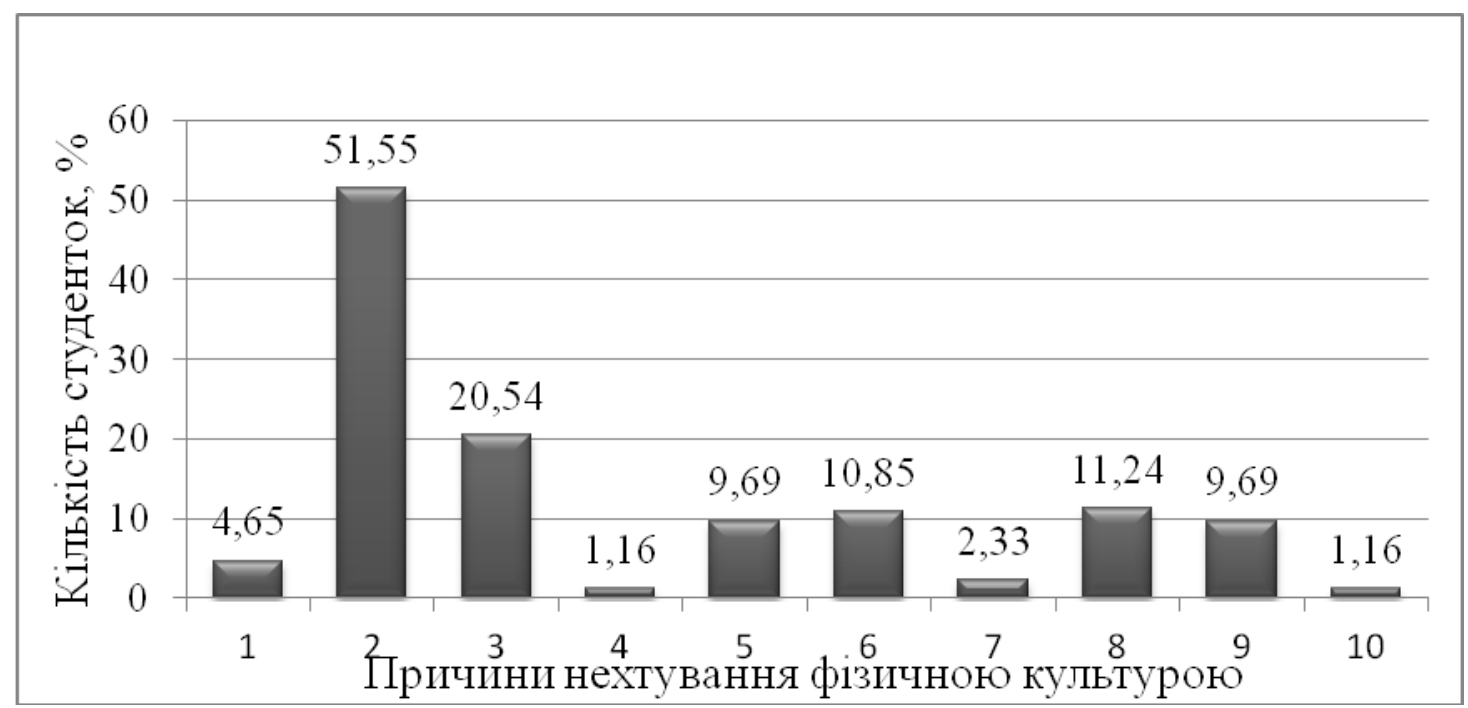

Рuc. 4. Розподіл студенток за причинами, які заважають займатися фізичною культурою $(\mathrm{n}=258), \%$ :

1 - відсутність спортивної бази і споруд за місцем проживання; 2 - немає вільного часу; 3 - не дозволяє стан здоров'я; 4 - немає можливості оплачувати заняття; 5 - немає бажання взагалі займатися спортом; 6 - немає компанії, 3 яким б я відвідував заняття; 7 - відсутність необхідних знань для організації самостійних занять; 8 - відсутність секцій з видів спорту, які мене цікавлять; 9 - відсутність спортивного одягу і взуття; 10 - відчуваю себе здоровим, тому і не займаюся.

Дискусія. Аналіз отриманих результатів дослідження свідчить, про те, що причиною не високого рівня рухової активності у студенток проходить на фоні падіння зацікавленості до занять з фізичної культури в закладах вищої освіти та пасивного ставлення до рухової діяльності взагалі. Отримані результати розширюють відомості [1, 3, $4,6]$ про особливості вмотивованості студенток до рухової активності та можливість отримання нової інформації, що послужить створенню психолого-педагогічних умов, які визначаються готовністю освітнього закладу забезпечити сприятливе освітнє середовище для професійного самовизначення студентів і формування позитивної мотивації до рухової активності.

\section{Висновки.}

1. 3'ясовано, що понад $50 \%$ студенток задоволені своїм професійним вибором, мають чіткий намір оволодіти обраним фахом, здійснювати в майбутньому безперервне професійне само удосконалення, прагнуть мати колег у обраній сфері майбутньої діяльності, виділяють свою професію серед інших.

2. В результаті анкетування встановлено дуже високий рівень інтересу до занять фізичною культурою виявили у 20,93\% студенток, 32,95\% - високий, 25,19\% - середній, 11,4\% - низький, а у 9,69\% така цікавість відсутня.

3. Найбільш поширеними мотивами до занять фізичною культурою є зміцнення здоров’я $(98,84 \%)$, поліпшення власної фізичної підготовленості $(84,50 \%)$ і покращення 
тіло будови (41,86\%). Серед причин, які є стримуючими щодо занять фізичною культурою студентки виділяють наступні: дефіцит часу $(51,55 \%)$, поганий стан здоров'я $(20,54 \%)$, відсутність спортивних секцій, які б їх зацікавили $(11,24 \%)$, партнерів для занять фізичними вправами $(10,85 \%)$, відсутність спортивного одягу і взуття $(9,69 \%)$.

1. Блавт ОЗ. Інформативні показники рівня фізичного здоров'я та фізичної підготовленості студентів ВНЗ. Педагогіка, психологія та медико-біологічні проблеми фізичного виховання і спорту: зб. наук. праць / під ред. С.С. Срмакова. 2012; 11: 14-8.

2. Жамардій В. Концептуальна модель застосування фітнес-технологій на заняттях із фізичного виховання студентів. Вищий державний навчальний заклад України. "Українська медична стоматологічна академія", Педагогічні науки: теорія, історія, інноваційні технології. 2018: 77-88

3. Kashuba V, Andrieieva O, Goncharova N, Kyrychenko V, Karp I, Lopatskyi S, Kolos M. Physical activity for prevention and correction of postural abnormalities in young women. Journal of Physical Education and Sport. University of Pitesti, Romania. 2019; 19(2): 500-6.

4. Максимова КВ, Мулик КВ. Актуальні питання збереження та зміцнення здоров'я студенток 17-21 років вищих навчальних закладів за рахунок фізкультурно-оздоровчих фітнес-занять. Вісник Кам'янець-Подільського національного університету імені Івана Огієнка. Фізичне виховання, спорт і здоров’я людини. 2017; 10: 301-11.

5. Земська Н. Характеристика рухової активності студентської молоді. Physical Education, Sport and Health Culture in Modern Society. 2016; 3: 19: 211-215.

6. Khlopetskyi V, Kuryliuk S. Correction of students negative states by health fitness means as a scientific problem = Корекція негативних станів студентів засобами оздоровчого фітнесу, як наукова проблема. Journal of Education, Health and Sport [Інтернет]. 2017; 7(2): 859-70. eISSN 2391-8306. Doi: http://dx.doi.org/10.5281/zenodo.3879686. URL: http://ojs.ukw.edu.pl/index.php/johs/article/view/7766.

\section{References}

1. Blavt O.Z. Informatyvni pokaznyky rivnia fizychnoho zdorovia ta fizychnoi pidhotovlenosti studentiv VNZ. Pedahohika, psykholohiia ta medyko-biolohichni problemy fizychnoho vykhovannia i sportu: zb. nauk. prats / pid red. S.S. Yermakova. 2012; 11: 14-18.

2. Zhamardii V. Kontseptualna model zastosuvannia fitnes-tekhnolohii na zaniattiakh iz fizychnoho vykhovannia studentiv. Vyshchyi derzhavnyi navchalnyi zaklad Ukrainy. "Ukrainska medychna stomatolohichna akademiia", Pedahohichni nauky: teoriia, istoriia, innovatsiini tekhnolohii. 2018; 3: 77-88

3. Kashuba V, Andrieieva O, Goncharova N, Kyrychenko V, Karr I, Lopatskyi S, Kolos M. Physical activity for prevention and correction of postural abnormalities in young women. Journal of Physical Education and Sport. University of Pitesti, Romania. 2019; 19(2): 500-6.

4. Maksymova K.V, Mulyk K.V. Aktualni pytannia zberezhennia ta zmitsnennia zdorovia studentok 17-21 rokiv vyshchykh navchalnykh zakladiv za rakhunok fizkulturno-ozdorovchykh fitnes-zaniat. Visnyk Kamianets-Podilskoho natsionalnoho universytetu imeni Ivana Ohiienka. Fizychne vykhovannia, sport i zdorovia liudyny. 2017; 10:301-11.

5. Zemska N. Kharakterystyka rukhovoi aktyvnosti studentskoi molodi. Physical Education, Sport and Health Culture in Modern Society. 2016; 3: 19: 211-5.

6. Khlopetskyi V, Kuryliuk S. Correction of students negative states by health fitness means as a scientific problem = Корекція негативних станів студентів засобами оздоровчого фітнесу, як наукова проблема. Journal of Education, Health and Sport [Інтернет]. 2017; 7(2): 859-70. eISSN 2391-8306. Doi: http://dx.doi.org/10.5281/zenodo.3879686. URL: http://ojs.ukw.edu.pl/index.php/johs/article/view/7766.

\section{Цитування на цю статтю:}

Хлопецький ВМ, Курилюк СІ, Мельник А, Мельник О. Професійне самовизначення та вмотивованість до рухової активності студенток педагогічних спеціальностей. Вісник Прикарпатського університету. Серія: Фізична культура. 2020 Листоп 24; 36: 94-100

\begin{tabular}{l|l|l} 
Відомості про автора: & Information about the author: \\
\hline Хлопецький Василь Михайлович - аспірант ка- & $\begin{array}{l}\text { Khlopetskyi Vasyl Mykhailovych - post-graduate } \\
\text { student of the Department of Theory and Methods of }\end{array}$ \\
федри теорії та методики фізичної культури і спор- \\
ту, ДВНЗ “Прикарпатський національний універ- \\
ситет імені Василя Стефаника” (Івано-Франківськ, \\
Україна)
\end{tabular}


e-mail: serhii.kuryliuk@pu.if.ua

https://orcid.org/0000-0003-1588-5756

Мельник Андрій - викладач, Прикарпатський Melnyk Andrii - Lecturer, Precarpathian Faculty of факультет Національної академії внутрішніх справ the National Academy of Internal Affairs (Ivano(Івано-Франківськ, Україна) Frankivsk, Ukraine)

https://orcid.org/0000-0003-1588-5756

Мельник Олена - викладач, Івано-Франківський фаховий коледж ДВНЗ "Прикарпатський національний університет імені Василя Стефаника" (Івано-Франківськ, Україна)

e-mail: serhii.kuryliuk@pu.if.ua

https://orcid.org/0000-0003-1588-5756

УДК 796. 378.093

doi: 10.15330/fcult.36.101-107

Ігор Випасняк, Богдан Мицкан, Тетяна Мицкан, Лілія Войчищин

\section{КОРЕКЦІЯ ПОРУШЕНЬ СКЛЕПННЧАСТОГО АПАРАТУ СТОПИ У МОЛОДШИХ ШКОЛЯРІВ ЗАСОБАМИ ТАЕКВОН-ДО}

Мета. Виявити вплив засобів таеквон-до на корекцію плоскостопості у молодших школярів. Методи. До педагогічного експерименту, за згодою батьків, було залучено 25 дітей чоловічої статі віком 7-10 років, з I-ІІ ступенем плоскостопості, з числа учнів 2-4 класів закладів середньої освіти м. Івано-Франківська. Секиійні заняття проводилися під керівництвом тренера-інструктора з таеквон-до тричі на тиждень протягом 9-ти місяиів, тривалістю 60 хвилин. Максимальна ЧСС не перевищувала 140 уд/хв. Для дослідження стопи використовували метод Е.Г. Мартиросова [4], який передбачає зняття відбитків підошовної поверхні стоп (плантограми). Результати. Виокремлюють наступні фактори, які впливають на розвиток плоскостопості: недорозвинені м'язи стопи, слабкість м'язово-зв'язкового апарату, надмірні фізичні навантаження, надлишкова вага, тривала гіпокінезія, неправильно підібране взуття, косолапість, ікс-подібна форма ніг, травми стопи та надп'ятковогомілкового суглобу, а також генетично детермінована форма стопи. Розробка нових $і$ вдосконалення існуючих засобів збереження соматичного здоров'я дітей молодшого шкільного віку та відновлення їх організму при різних порушеннях є одним із важливих завдань фізичної культури. В иъьому контексті була розроблена інноваційна програма для дітей молодшого шкільного віку з порушеннями склепінчастого апарату стопи. В підготовчій частині заняття, окрім гімнастичних вправ для різних груп м'язів, використовували комплекс суглобової гімнастики з метою підготовки організму молодших школярів до виконання технічних елементів таеквон-до. В основній частині заняття акиент робився на вивчення й удосконалення базових ударів ногами, а в заключній використовували релаксачійні вправи, самомасаж, дихальну гімнастику. Аналіз плантограм зроблених до початку $і$ в кінці педагогічного експерименту дозволив встановити вірогідне покращення коефіцієнту $K$, пяточного кута $i$ кутів біля першого $i$ n'ятого пальців, щуо $\epsilon$ свідченням повної корекиії плоскостопості. Висновок. Отже встановлено, щуо комплексне застосування засобів таеквон-до і суглобової гімнастики забезпечує нормалізацію склепінчастого апарату стопи у дітей молодшого шкільного віку з I-II ступенем плоскостопості.

Ключові слова: молодші школярі, плоскостопість, таеквондо.

Aim. Identify the effect of taekwondo on the correction of flat feet in younger students. Methods. With the consent of parents, 25 male children aged 7-10 years, with I-II degree of flat feet, from among students of 2-4 grades of secondary schools in Ivano-Frankivsk were involved in the pedagogical experiment. Sectional classes were conducted under the guidance of a taekwondo coach up to three times a week for 9 months, lasting 60 minutes. The maximum heart rate did not exceed 140 beats / min. To study the foot used the method of Martirosov EG [4], which involves taking footprints of the plantar surface of the feet (plantogram). Results. There are the following factors that affect the development of flat feet: underdeveloped foot muscles, weakness of the musculoskeletal system, excessive exercise, overweight, prolonged hypokinesia, improperly selected shoes, clubfoot, X-shaped legs, foot injuries and ankle joint, as well as genetically determined shape of the foot. The development of new and improvement of existing means of maintaining the physical health of children of primary school age and the recovery of their bodies in various disorders is one of the important tasks of physical culture. In this context, an innovative program was developed for children of primary school age with disorders of the arch of the foot. In the preparatory part of the lesson, in addition to gymnastic exercises for different 